\title{
Gonadotrophin release in ovariectomized ewes fed different amounts of coumestrol
}

\author{
G. W. Montgomery*, G. B. Martin†, J. Le Bars $\ddagger$ and J. Pelletier
}

I.N.R.A., Station de Physiologie, Centre de Recherches de Tours, 37380 Monnaie, and $\ddagger$ I.N.R.A., Station de Pharmacologie Toxicologie, 180 Chemin de Tournefeuille, 31300 Toulouse, France

\begin{abstract}
Summary. Three experiments were conducted to study changes in pulsatile secretion of $\mathrm{LH}$ and FSH during the breeding season or anoestrus in ovariectomized Ile-de-France ewes fed different amounts of the phyto-oestrogen coumestrol. In Exp. 1, conducted during the breeding season, ewes (3-4 per group) were fed lucerne supplying 4, 18 or 30 $\mathrm{mg}$ coumestrol per ewe per day for 15 days. Experiments 2 and 3 were conducted during seasonal anoestrus. In Exp. 2, ewes (4 per group) were fed lucerne supplying coumestrol concentrations ranging from 4 to $38 \mathrm{mg} /$ ewe/day for 15 days. In Exp. 3, ewes (10 per group) were fed lucerne supplying 14 or $125 \mathrm{mg}$ coumestrol/ewe/day for 15 days. During the breeding season, an increased concentration of coumestrol in the diet significantly decreased the amplitude of LH pulses. There were no effects on LH pulse frequency or on FSH concentrations. During seasonal anoestrus, there were no significant effects on LH pulse frequency, or amplitude and no significant effect on FSH concentration. These results show that high concentrations of coumestrol in lucerne diets would not explain seasonal variation in LH pulse frequency in ovariectomized ewes. However, lucerne diets with increased coumestrol concentrations can influence LH release during the breeding season.
\end{abstract}

\section{Introduction}

Luteinizing hormone $(\mathrm{LH})$ release varies with season in ovariectomized ewes given oestradiol implants and it has been proposed that photoperiod controls seasonal breeding in the ewe by changing the response of the hypothalamic-pituitary system to feedback effects of oestradiol (Legan, Karsch \& Foster, 1977). During seasonal anoestrus, oestradiol inhibits the secretion of LH primarily by reducing the frequency of LH pulses (for review see Martin, 1984). Conversely, during the breeding season oestradiol increases the frequency of LH pulses and reduces pulse amplitude (Karsch, Foster, Bittman \& Goodman, 1983). In addition, seasonal changes in LH secretion have been observed in ovariectomized ewes in the absence of exogenous oestrogen (Goodman, Bittman, Foster \& Karsch, 1982; Montgomery, Martin \& Pelletier, 1985). In ovariectomized Ile-de-France ewes, the frequency of LH pulses varied from one pulse every $35 \mathrm{~min}$ during the breeding season to one pulse every $60 \mathrm{~min}$ during anoestrus (Montgomery et al., 1985). There are therefore 'direct' effects of season on the frequency of LH pulses and seasonal changes in responsiveness to oestradiol feedback. However, the seasonal variation in LH pulse frequency that occurs in ovariectomized ewes may result from the effects of extra-ovarian steroids from the adrenal glands and/or oestrogenic substances in the diet (Goodman et al., 1982).

Lucerne (alfalfa) is a common component in sheep diets and has been shown to contain the

* Present address: Invermay Agricultural Research Centre, Private Bag, Mosgiel, New Zealand. U.K.

† Present address: MRC Reproductive Biology Unit, Centre for Reproductive Biology, Edinburgh EH3 9EW, 
phyto-oestrogen coumestrol (Bickoff et al., 1957; Livingston, Bickoff, Guggolz \& Thompson, 1961). Coumestrol is structurally similar to steroidal oestrogens and will induce increased teat length in wethers (Millington, Francis \& McKeown, 1964), increased uterine weight in ovariectomized ewes (Braden, Hart \& Lamberton, 1967), decreased ovulation rate (Smith, Jagusch, Brunswick \& McGowan, 1980), inhibition of oestrous behaviour and altered pituitary morphology (Kelly, Adams \& Lindsay, 1976). Coumestrol has been shown to compete with oestradiol for binding sites on a macro-molecular component of uterine cytosol and to be present in blood after ingestion of lucerne hay (Shemesh, Lindner \& Ayalon, 1972). However, the effects of coumestrol on gonadotrophin secretion have not been studied and the experiments described here were designed to test the effect of dietary coumestrol on the secretion of LH and FSH in ovariectomized ewes.

\section{Materials and Methods}

Animals and management. Three experiments were conducted with Ile-de-France ewes 3-5 years of age. Ewes were housed in rooms $\left(32 \mathrm{~m}^{2}\right)$ in a light-proof building, isolated from rams, and subjected to normal seasonal changes in daylength regulated by electrical clocks. Daylength varies from about $8 \mathrm{~h}$ in December to $16 \mathrm{~h}$ in June at the latitude of $47^{\circ} \mathrm{N}$ at Nouzilly. The clocks were adjusted every 2-4 days according to the magnitude of the daily change in daylength. In each room, $8 \times$ 40-W, white fluorescent tubes provided about 300 lux at the level of the ewes' eyes when animals looked directly at the lights. Ewes were fed each morning and had water available ad libitum.

A period of at least 1 month was allowed for ewes to adjust to the environment before the start of the experiments. All ewes were ovariectomized at mid-ventral laparotomy under anaesthesia as described previously (Montgomery et al., 1985). During the breeding season, ovaries were removed from ewes on Day 9 of oestrous cycles that had been synchronized with two injections (125 $\mu \mathrm{g}$ each) of cloprostenol (Estrumate: ICI Ltd), 9 days apart.

Diets. The standard diet consisted of $300 \mathrm{~g}$ lucerne pellets, $400 \mathrm{~g}$ wheat, $30 \mathrm{~g}$ mineral supplement and wheat straw ad libitum. These proportions were maintained except for Exp. 3 when ewes were fed $1 \mathrm{~kg}$ lucerne pellets, $30 \mathrm{~g}$ mineral supplement and wheat straw ad libitum. Different sources of lucerne pellets were analysed for coumestrol content (see below) and 3 were chosen for the experiments. The 3 sources contained about 14, 125 and 135 p.p.m. coumestrol.

During each experiment, representative samples of lucerne pellets were collected twice each week for analysis of coumestrol content.

Experiment 1. Ewes were randomly allocated to 3 treatment groups. The experiment was conducted in November and December during the normal breeding season (Thimonier \& Mauleon, 1969) and all 10 ewes had been ovariectomized 17 days before the beginning of experimental feeding. Ewes were fed lucerne supplying 4,18 or $40 \mathrm{mg}$ coumestrol/ewe/day for 15 days and then blood samples were collected ( 1 December) from catheters placed in the jugular veins the previous day. Samples were collected every $10 \mathrm{~min}$ for $6 \mathrm{~h}$ beginning at 09:00 h.

Experiment 2. Ewes were randomly allocated to 5 treatment groups. The experiment was conducted in April during the period of seasonal anoestrus (Thimonier and Mauleon, 1969) and all 20 ewes had been ovariectomized 25 days before the beginning of experimental feeding. Ewes were fed lucerne supplying 4, 15, 25, 30 or $38 \mathrm{mg}$ coumestrol/ewe/day for 15 days and then blood samples were collected ( 26 April) from catheters placed in the jugular veins the previous day. Samples were collected every $10 \mathrm{~min}$ for $9 \mathrm{~h}$ beginning at 09:00 h.

Experiment 3. At 2 weeks after Exp. 2 the 20 ewes were re-randomized to two treatment groups and fed diets containing $1 \mathrm{~kg}$ lucerne pellets. Ewes were fed lucerne supplying 14 or $125 \mathrm{mg}$ coumestrol/ewe/day for 15 days and then blood samples were collected ( 1 June) from catheters placed in the jugular veins the previous day. Samples were collected every $10 \mathrm{~min}$ for $9 \mathrm{~h}$ beginning at $09: 00 \mathrm{~h}$. 
Coumestrol assay. The coumestrol content of lucerne pellets was assayed according to the method of Le Bars \& Le Bars (1984). Samples were ground and thoroughly mixed. Sub-samples of $5 \mathrm{~g}$ were re-hydrated with $50 \mathrm{ml}$ distilled water for $30 \mathrm{~min}$ and extracted with $100 \mathrm{ml}$ methyl alcohol for $1 \mathrm{~h}$. The solution was filtered and $50 \mathrm{ml}$ added to $100 \mathrm{ml}$ sodium carbonate solution $(0.5 \mathrm{M}$, $\mathrm{pH} 10.9)$ and extracted 3 times with chloroform. The aqueous phase was acidified with sulphuric

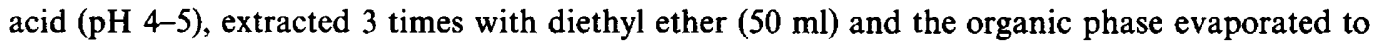
dryness.

The extract was re-dissolved in $200 \mu \mathrm{l}$ of $85 \%$ ethanol. A $50 \mu \mathrm{l}$ sample was applied to thin-layer chromatography plates and developed in chloroform-acetone $(18: 12, \mathrm{v} / \mathrm{v})$. The band corresponding to coumestrol was gently scraped off the plates, extracted with $5 \mathrm{ml} \mathrm{of} 85 \%$ ethanol and centrifuged. The concentration of coumestrol in the final extract was determined by fluorometry (Perkin Elmer MPF 3L, maximum excitation $365 \mathrm{~nm}$, maximum emission $415 \mathrm{~nm}$ ) by comparison with standard solutions of coumestrol (Apin Chemicals, Oxford, U.K.). The limit of detection in the final extract was $0 \cdot 1 \mathrm{ng} / \mathrm{ml}$.

LH assay. LH was measured in duplicate in a double-antibody radioimmunoassay (Pelletier, Kann, Dolais \& Rosselin, 1968), with the modifications recently described (Pelletier, Garnier, de Reviers, Terqui \& Ortavant, 1982). The sensitivity of the assay was $0.5 \mathrm{ng} / \mathrm{ml}$ and the intra-assay coefficient of variation was $<10 \%$. All samples from the same experiment were measured in the same assay.

FSH assay. FSH concentrations were measured in duplicate by an homologous radioimmunoassay using CNRS-FSH-P26 (equiv. to $14 \times \mathrm{NIH}-\mathrm{FSH}-\mathrm{S}_{3}$ ) as standard and HG-FSH-225226 (equiv. to $36 \times$ NIH-FSH-S 3 ) as labelled tracer (Blanc \& Poirier, 1979). Cross-reactions with other pituitary hormones were small (TSH $1-2 \%$; all others $\leq 0.02 \%$ ). Sensitivity of the assay was 2 $\mathrm{ng} / \mathrm{ml}$. The intra-assay coefficient of variation was $8 \%$ at a value of $\mathrm{B} / \mathrm{Bo}$ of $50 \%$. All samples from the same experiment were measured in the same assay.

Data analysis. Pulses of LH in individual profiles were identified as described by Goodman \& Karsch (1980). For each profile, mean nadir, mean amplitude and mean interval between pulses were calculated for complete pulses as described previously (Montgomery et al., 1985). Data for variables describing pulsatile LH secretion and concentrations of FSH were assessed by analyses of variance.

\section{Results}

\section{Breeding season}

Mean ewe liveweight was $66.8 \mathrm{~kg}$ and there was no significant change in liveweight during the period of differential feeding (67.0 and $66.6 \mathrm{~kg}$, s.e. of difference 0.31$)$. Increased concentration of coumestrol in the diet did not significantly affect mean nadir or mean interval between LH pulses (Table 1). In contrast, an increased concentration of coumestrol significantly $(P<0.05)$ reduced the amplitude of LH pulses (Table 1). The amplitude of pulses for ewes on the control diet was $10 \cdot 3$ $\mathrm{ng} / \mathrm{ml}$ and was decreased to $4.2 \mathrm{ng} / \mathrm{ml}$ in ewes fed the diet supplying coumestrol at $40 \mathrm{mg} / \mathrm{ewe} /$ day (s.e. of difference 2.3). At the intermediate dose, pulse amplitude was reduced to that observed on the high diet in 2 ewes and 1 ewe did not respond. There was no significant effect of concentration of coumestrol on mean FSH concentrations (Table 1).

\section{Anoestrous season}

During the two experiments conducted in the anoestrous season, the ewes gained $3 \mathrm{~kg}(61.7$ versus $64.7 \mathrm{~kg}$, s.e. of difference 0.43 ). However, during the periods of experimental feeding, liveweight changes between treatments did not differ significantly when the ewes were fed $300 \mathrm{~g}$ lucerne pellets (Exp. 2) or $1 \mathbf{~ k g}$ lucerne pellets (Exp $\$$ B) Ioaded from Bioscientifica.com at 04/26/2023 11:39:58AM 
Table 1. The effect of feeding lucerne containing different concentrations of coumestrol on characteristics of $\mathrm{LH}$ release and on $\mathrm{FSH}$ concentration in ovariectomized ewes during the breeding season

\begin{tabular}{|c|c|c|c|c|}
\hline & \multicolumn{3}{|c|}{$\begin{array}{l}\text { Coumestrol content of } \\
\text { diet }(\mathrm{mg} / \mathrm{ewe} / \text { day })\end{array}$} & \multirow{2}{*}{$\begin{array}{c}\text { s.e. of } \\
\text { difference }\end{array}$} \\
\hline & 4 & 18 & 40 & \\
\hline $\begin{array}{l}\text { No. of ewes } \\
\text { LH pulses }\end{array}$ & 3 & 3 & 4 & \\
\hline Mean interval (min) & 41.8 & $42 \cdot 1$ & $39 \cdot 2$ & $4 \cdot 1$ \\
\hline Mean amplitude ( $\mathrm{ng} / \mathrm{ml})$ & $10 \cdot 3$ & $6 \cdot 2$ & $4 \cdot 2$ & $2 \cdot 3$ \\
\hline Mean nadir (ng/ml) & 6.8 & $3 \cdot 4$ & $4 \cdot 7$ & 1.6 \\
\hline FSH conc. $(\mathrm{ng} / \mathrm{ml})$ & $26 \cdot 1$ & 25.9 & $26 \cdot 2$ & 0.6 \\
\hline
\end{tabular}

Table 2. The effect of feeding lucerne containing different concentrations of coumestrol on characteristics of $\mathrm{LH}$ release and on FSH concentration in ovariectomized ewes during seasonal anoestrus

\begin{tabular}{|c|c|c|c|c|c|c|}
\hline & \multicolumn{5}{|c|}{$\begin{array}{l}\text { Coumestrol content of } \\
\text { diet }(\mathrm{mg} / \text { ewe/day })\end{array}$} & \multirow{2}{*}{$\begin{array}{c}\text { s.e. of } \\
\text { difference }\end{array}$} \\
\hline & 4 & 15 & 25 & 30 & 38 & \\
\hline $\begin{array}{l}\text { No. of ewes } \\
\text { LH pulses }\end{array}$ & 5 & 5 & 5 & 5 & 5 & \\
\hline Mean interval (min) & $48 \cdot 0$ & $46 \cdot 1$ & $49 \cdot 2$ & $46 \cdot 2$ & $52 \cdot 4$ & $5 \cdot 2$ \\
\hline Mean amplitude (ng/ml) & 4.5 & 5.4 & 5.0 & $5 \cdot 6$ & 8.8 & $2 \cdot 0$ \\
\hline Mean nadir $(\mathrm{ng} / \mathrm{ml})$ & 3.6 & $3 \cdot 6$ & $3 \cdot 6$ & $4 \cdot 6$ & $4 \cdot 4$ & 0.5 \\
\hline FSH conc. $(\mathrm{ng} / \mathrm{ml})$ & $24 \cdot 8$ & $24 \cdot 6$ & 24.8 & $24 \cdot 4$ & $24 \cdot 4$ & 0.7 \\
\hline
\end{tabular}

Table 3. The effect of feeding lucerne containing 14 or $125 \mathrm{mg}$ coumestrol per $\mathrm{kg}$ on characteristics of LH release and FSH concentration in ovariectomized ewes during seasonal anoestrus

\begin{tabular}{lccc}
\hline & \multicolumn{2}{c}{$\begin{array}{c}\text { Coumestrol content of } \\
\text { diet (mg/ewe/day) }\end{array}$} & $\begin{array}{c}\text { s.e. of } \\
\text { difference }\end{array}$ \\
\cline { 2 - 3 } & 14 & 125 & \\
\hline No. of ewes & 10 & 10 & \\
LH pulses & & & \\
$\quad$ Mean interval $(\mathrm{min})$ & $49 \cdot 5$ & $45 \cdot 7$ & 2.94 \\
Mean amplitude $(\mathrm{ng} / \mathrm{ml})$ & $4 \cdot 2$ & $2 \cdot 7$ & 0.76 \\
Mean nadir $(\mathrm{ng} / \mathrm{ml})$ & $3 \cdot 1$ & $2 \cdot 6$ & 0.46 \\
FSH conc. $(\mathrm{ng} / \mathrm{ml})$ & 27 & 27 & $2 \cdot 1$ \\
\hline
\end{tabular}

Experiment 2. There were no significant effects of dose of coumestrol on any characteristics of LH release (Table 2) or on the concentrations of FSH (Table 2).

Experiment 3. There was no significant effect of feeding $1 \mathrm{~kg}$ lucerne pellets per day providing 14 or $125 \mathrm{mg}$ coumestrol/ewe/day on the interval between LH pulses or mean nadir (Table 3). The amplitude of pulses was lower in ewes fed $125 \mathrm{mg}$ coumestrol/ewe/day compared with control ewes $(2.75$ and 4.22 , s.e. of difference 0.758$)$ but the difference failed to reach significance $(0.1>P>$ 0.05 ). Concentrations of FSH did not differ significantly between the diets (Table 3 ). 


\section{Discussion}

Despite reported 'oestrogenic' effects of coumestrol in sheep, there was no evidence from the present results that feeding increased amounts of coumestrol for 15 days during seasonal anoestrus reduced the frequency of $\mathbf{L H}$ pulses below that for the control diet. This result contrasts with the potent inhibitory effects of oestradiol on LH pulse frequency during seasonal anoestrus (Karsch, 1980; Goodman et al., 1982; Martin, Scaramuzzi \& Henstridge, 1983). Feeding coumestans to ewes for as little as 7 days can depress ovulation rate and a significant depression occurs when ewes are fed $50 \mathrm{mg} /$ ewe/day (Smith et al., 1980). The period of feeding and the high concentration of coumestrol fed in Exp. 3 should have been sufficient to demonstrate any effects on LH pulse frequency.

Seasonal variation in LH pulse frequency occurs in ewes in the absence of the ovaries (Goodman et al., 1982; Montgomery et al., 1985), although such variation could be due to the effects of extra-ovarian steroids from the food supply and/or the adrenal glands (Karsch, 1980; Goodman et al., 1982). From the present experiment it is unlikely that coumestrol in lucerne diets would contribute to the seasonal variation in LH pulse frequency in ovariectomized ewes. Indeed, experiments describing differences in the pattern of change in LH pulse frequency after ovariectomy during either anoestrus or the breeding season (Montgomery et al., 1985) were conducted with ewes fed diets containing low concentrations of coumestrol.

During the breeding season, increased coumestrol concentration in the diet resulted in a decrease in the amplitude of LH pulses. Data on LH release were available for the same ewes immediately before feeding the experimental diets (15 days after ovariectomy). Covariance analysis showed that the relationship between pulse amplitude before and after feeding different coumestrol diets was small and non-significant. As a consequence, mean pulse amplitudes adjusted for amplitudes recorded in the same ewes before feeding the experimental diets, were similar to the unadjusted values. In entire ewes, oestradiol reduces the amplitude of LH pulses (Goodman \& Karsch, 1980; Wright, Geytenbeek, Clarke \& Findlay, 1981; Karsch et al., 1983) and contributes to the increase in frequency during the follicular phase of the cycle (Karsch et al., 1983). The decrease in pulse amplitude observed with increased concentration of coumestrol in the diet is consistent with effects of oestradiol during the breeding season.

We did not detect an increase in pulse frequency in ewes fed coumestrol during the breeding season. The frequency in control ewes was similar to that in oestradiol-treated ewes in the experiments of Karsch et al. (1983). Over a wide range of frequencies and amplitudes there is a reciprocal relationship between frequency and amplitude (Goodman \& Karsch, 1980; Goodman et al., 1982; Martin et al., 1983). However, amongst sampling days within ewes, there was no significant relationship between LH pulse frequency and amplitude during the first 15 days after ovariectomy $(r=0.02 ;$ G. W. Montgomery, G. B. Martin \& J. Pelletier, unpublished observations).

When the data from all three experiments are considered together, they show that dietary coumestrol can affect the amplitude of LH pulses, but does not affect LH pulse frequency, particularly during the period of seasonal anoestrus. The effect of oestradiol on the frequency of LH pulses is thought to act primarily at the level of the hypothalamus (see Martin, 1984). The data therefore suggest that coumestrol may not act at hypothalamic sites, but could be active at the pituitary to reduce the amplitude of $\mathrm{LH}$ pulses during the breeding season. Studies with the phytooestrogen equol are consistent with that interpretation. Equol is able to bind to uterine and hypothalamic receptors in vitro (Mathieson \& Kitts, 1980). However, studies in vivo have shown reduced ability of equol to compete with oestradiol for oestrogen receptors in the hypothalamus compared with the uterus (Adams \& Tang, 1981), suggesting impaired transport into the hypothalamus.

Differences in LH release during the preovulatory period are not thought to be associated with differences in ovulation rate since widely different types of LH delivery to the ovary do not result in 
changes in ovulation rate (McNatty, Gibb, Dobson \& Thurley, 1981). However, differences in FSH concentration during the preovulatory period have been associated with differences in ovulation rate in Booroola Merino ewes (Bindon et al., 1984). In the present experiment there was no effect of coumestrol on FSH concentration during the breeding season, while the amplitude of LH pulses was reduced, raising the possibility that the amplitude of $\mathrm{LH}$ pulses may be associated with effects of coumestrol on ovulation rate. However, direct effects of coumestrol on the ovary, or indirect effects on FSH release through inhibin production cannot be excluded.

In conclusion, a high concentration of coumestrol in lucerne diets would not explain seasonal variation in LH pulse frequency in ovariectomized ewes. However, lucerne diets with increased coumestrol concentrations can influence $\mathrm{LH}$ release during the breeding season.

We thank Alain Locatelli, Marie-Odile Moulin, Didier Chesneau and Claude Cornu for technical assistance; Martial Charpentier for providing lucerne pellets differing in coumestrol concentration; and Michel Blanc and Jean-Claude Poirier for help with the FSH assays. G.W.M. was supported by a New Zealand Public Service Study Award and a Bourse de Stage, and G.B.M. by an Overseas Study Award from the Australian Meat Research Council.

\section{References}

Adams, N.R. \& Tang, B.Y. (1981) Impaired binding of the phyto-oestrogen equol in the hypothalamus, compared with the uterus. Proc. Endocr. Soc. Aust. 24, 64, Abstr.

Bickoff, E.M., Booth, A.N., Lyman, R.L., Livingston, A.L., Thompson, C.R. \& DeEds, F. (1957) Coumestrol, a new estrogen isolated from forage crops. Science, N.Y. 126, 969-970.

Bindon, B.M., Piper, L.R., Cummins, L.J., O'Shea, T., Hilliard, M.A., Findlay, J.K. \& Robertson, P.M. (1984) Reproductive endocrinology of prolific sheep: studies of the Booroola merino. In Genetics of Reproduction in Sheep, pp. 217-236. Eds R. B. Land \& D. W. Robinson. Butterworths, London.

Blanc, M.R. \& Poirier, J.C. (1979) A new homologous radioimmunoassay for ovine follicle stimulating hormone: development and characterisation. Annls Biol. anim. Biochim. Biophys. 19, 1011-1026.

Braden, A.W.H., Hart, N.K. \& Lamberton, J.A. (1967) The oestrogenic activity and metabolism of certain isoflavones in sheep. Aust. J. agric. Res. 18, 335-348.

Goodman, R.L. \& Karsch, F.J. (1980) Pulsatile secretion of luteinizing hormone: differential suppression by ovarian steroids. Endocrinology 107, 1286-1290.

Goodman, R.L., Bittman, E.L., Foster, D.L. \& Karsch, F.J. (1982) Alterations in the control of luteinizing hormone pulse frequency underlie the seasonal variation in estradiol negative feedback in the ewe. Biol. Reprod. 27, 580-589.

Karsch, F.J. (1980) Seasonal reproduction: a saga of reversible fertility. Physiologist, Wash. 23, 29-38.

Karsch, F.J., Foster, D.L., Bittman, E.L. \& Goodman, R.L. (1983) A role for estradiol in enhancing luteinizing hormone pulse frequency during the follicular phase of the estrous cycle of the sheep. Endocrinology 113, 1333-1339.

Kelly, R.W., Adams, N.R. \& Lindsay, D.R. (1976) Effect of coumestans on reproduction in the ewe. Aust. $J$. agric. Res. 27, 253-259.

Le Bars, J. \& Le Bars, P. (1984) Methodes pratiques du dosage du coumestrol dans la luzerne et ses derives. Rev. Med. Vet. 135, 73-76.

Legan, S.J., Karsch, F.J. \& Foster, D.L. (1977) The endocrine control of seasonal reproductive function in the ewe: a marked change in the response to the negative feedback action of estradiol on luteinizing hormone secretion. Endocrinology 101, 818-824.

Livingston, A.L., Bickoff, E.M., Guggolz, J. \& Thompson, C.R. (1961) Quantitative determination of coumestrol in fresh and dried alfalfa. J. agric. Fd Chem. 9, 135-137.

Martin, G.B. (1984) Factors affecting the secretion of luteinizing hormone in the ewe. Biol. Rev. 59, 1-87.

Martin, G.B., Scaramuzzi, R.J. \& Henstridge, J.D. (1983) Effects of oestradiol, progesterone and androstenedione on the pulsatile secretion of luteinizing hormone in ovariectomized ewes during spring and autumn. J. Endocr. 96, 181-193.

Mathieson, R.A. \& Kitts, W.D. (1980) Binding of phytooestrogen and oestradiol-17 $\beta$ by cytoplasmic receptors in the pituitary gland and hypothalamus of the ewe. J. Endocr. 85, 317-325.

McNatty, K.P., Gibb, M., Dobson, C. \& Thurley, D.C. (1981) Evidence that changes in luteinizing hormone secretion regulate the growth of the pre-ovulatory follicle in the ewe. J. Endocr. 90, 375-389.

Millington, A.J., Francis, C.M. \& McKeown, N.R. (1964) Wether bioassay of annual pasture legumes. I. Oestrogenic activity in Medicago tribuloides descr. var. cyprus relative to four strains of Trifolium subterraneum. Aust. J. agric. Res. 15, 520-526.

Montgomery, G.W., Martin, G.B. \& Pelletier, J. (1985) Changes in pulsatile $\mathrm{LH}$ secretion following ovariectomy in Ile-de-France ewes in two seasons. J. Reprod. Fert. 73, 173-183.

Pelletier, J., Kann, J., Dolais, J. \& Rosselin, G. (1968) Dosage radioimmunologique de l'hormone luteinisante plasmatique chez le mouton. Mise au point de la technique de dosage. C. r. hebd. Séanc. Acad. Sci., Paris D 266, 2291-2294. 
Pelletier, J., Garnier, D.H., de Reviers, M.M., Terqui, M. \& Ortavant, R. (1982) Seasonal variation in LH and testosterone release in rams of two breeds. J. Reprod. Fert. 64, 341-346.

Shemesh, M., Lindner, H.R. \& Ayalon, N. (1972) Affinity of rabbit uterine oestradiol receptor for phytooestrogens and its use in a competitive proteinbinding radioassay for plasma coumestrol. J. Reprod. Fert. 29, 1-9.

Smith, J.F., Jagusch, K.T., Brunswick, L.F.C. \& McGowan L.T. (1980) The effect of lucerne feeding on ovulation rate in ewes. Proc. N.Z. Soc. Anim. Prod. 40, 44-49.
Thimonier, J. \& Mauleon, P. (1969) Variations saisonnieres du comportement d'oestrus et des activites ovarienne et hypophysaire chez les ovins. Annls Biol. anim. Biochim. Biophys. 9, 233-250.

Wright, P.J., Geytenbeek, P.E., Clarke, I.J. \& Findlay, J.K. (1981) Evidence for a change in oestradiol negative feedback and LH pulse frequency in postpartum ewes. J. Reprod. Fert. 61, 97-102.

Received 25 June 1984 